\title{
Black, White, and Grey
}

\section{The Wicked Problem of Virtual Reality in Libraries}

\author{
Gillian D. Ellern and Laura Cruz
}

\section{ABSTRACT}

This study seeks to extend wicked problems analysis within the context of a library's support for virtual reality (VR) and the related extended reality (XR) emerging technologies. The researchers conducted 11 interviews with 13 librarians, embedded IT staff, and/or faculty members who were involved in administering, managing, or planning a virtual reality lab or classroom in a library (or similar unit) in a higher education setting. The qualitative analysis of the interviews identified clusters of challenges, which are categorized as either emergent (but solvable) such as portability and training; complicated (but possible) such as licensing and ethics: and/or wicked (but tameable). The respondents framed their role in supporting the wickedness of VR/XR in three basic ways: library as gateway, library as learning partner, and library as maker. Five taming strategies were suggested from this research to help librarians wrestle with these challenges of advocating for a vision of $V R / X R$ on their respective campuses. This research also hints at a larger role for librarians in the research of technology diffusion and what that might mean to their role in higher education in the future.

\section{INTRODUCTION}

Political scientists Horst Rittel and Melvin Webber coined the term "wicked problems" in the early 1970 s to refer to problems that were sufficiently complex that they defied conventional problemsolving methods. ${ }^{1}$ Initially framed as broad social problems, such as food security or climate change, wicked problems are characterized by having ambiguous parameters, shifting requirements and/or stakeholders, and, perhaps more importantly, "no determinable stopping point." ${ }^{2}$ Such problems are called wicked because they are "diabolical, in that they resist the usual attempts to resolve them."3 Without the possibility of a clear solution, the end product of wicked problems analysis is not to solve the problem but rather to find ways to "tame" them, an approach which runs counter to conventional models of not only planning but also reasoning. ${ }^{4}$

If taming is the last step in wicked problems analysis, a critical first step is to determine if a given challenge is, in fact, wicked, as that will then determine what tools, perspectives, and strategies will need to be brought to the table. Simple problems can be resolved by matching them to known solutions, more complicated problems may be addressed by analyzing engineering solutions, but super complex/messy/wicked problems require an entirely different mindset. ${ }^{5}$ Persistent frustration with the limitations of conventional problem-solving models has led to a proliferation of studies identifying a host of wicked problems, ranging from the global (COVID-19 response) to the local (dysfunctional families). ${ }^{6}$ The present study seeks to apply the framework of wicked problem analysis to the question of the role of academic libraries in supporting emerging technologies, using the integration of VR/XR as a case study.

Gillian D. Ellern (ellern@email.wcu.edu) is Associate Professor and Systems Librarian, Hunter Library, Western Carolina University. Laura Cruz (lxc601@psu.edu) is Associate Research Professor, Schreyer Institute for Teaching Excellence, The Pennsylvania State University. (C) 2021. 


\section{LITERATURE REVIEW}

The wicked problem of libraries and technology has been recognized by a number of scholars, each using a different frame of reference, as perhaps fits the inherent ambiguity of a wicked problem. Scholars have identified electronic data management, research data management, and ebooks as library problems that are wicked in nature, and Howley notes that the question of public access touches on larger social issues that could be described as wicked. ${ }^{7}$ A recent article by Williams and Willet identifies makerspace technology as boundary work, suggesting that it challenges conventional roles and relationships held by libraries and librarians, an approach which implies the existence a wicked problem. ${ }^{8}$ Despite these exceptions, at least one set of library scholars has noted that "there are very few applications [of wicked problems] in librarianship." The present study seeks to make the case that the application of the wicked problems framework to the question of the role of the libraries in emerging technology can illuminate new strategies, roles, and pathways forward.

While research on wicked problems in libraries may be limited, the role of libraries in the curation, development, and dissemination of virtual reality (VR) — or using the more encapsulated term of extended reality (XR) - has been extensively written about by library scholars. Although it could be argued that the current output reflects the nascent stages of VR/XR as a research field as scholars explore a library's role with virtual reality (VR), mixed reality (MR), augmented reality (AR), and everything associated with them such as virtual worlds or 3D 360-degree videos, it is clear that, to date, the published works about VR/XR largely fall into two camps: the visionary and the applied. The former contains studies advocating for the integration of VR/XR (and related technologies) as part of a vision of the future for libraries; and the latter are applied studies that Booth labels as "technorealistic."10 In other words, these are descriptions of established practice or suggestions of practical strategies for how a library (or librarian) can actually implement a VR/XR lab or related program. ${ }^{11}$ What remains in shorter supply are critical and/or empirical studies that situate the development of VR/XR as an institutional capacity into larger, arguably wicked, questions of the evolving purpose and position of libraries.

The case of VR/XR presents a distinctive perspective on the wicked problem of the technological orientation of academic libraries. Unlike issues such as electronic records management, VR/XR is not part of the core technological infrastructure of a library, nor does it touch directly upon prior core administrative functions, such as collection development or access services. Rather, it is perceived as an extension of library services, particularly those related to the evolving educational mission of the academic library and its role as a broader facilitator of information literacy across disciplines. As one library scholar remarks:

As libraries are increasingly called upon to support knowledge exchange beyond traditional books and journals, the creation of novel types of research infrastructure will shape the preservation and access expectations of constituents. ${ }^{12}$

The present study looks at how librarians navigate, or tame, the myriad of challenges that arise not just from rethinking how an academic library engages with technology, but from pushing the boundaries of what library work is (or could be).

As the emergence of VR/XR technology begins to cast a larger shadow over higher education, many librarians have argued that academic libraries associated with institutions with high research activity are especially well situated to take on a leadership role, an opportunity that they 
had largely missed with recent related technologies such as 3D printing. Not wanting to be left behind, these libraries have embraced VR/XR technology at a relatively rapid rate. A recent (unpublished) study noted that in 2015, only $3 \%(n=4)$ out of the 125 sampled research universities had a VR/XR presence; by 2020 , that percentage increased to $66 \%(n=77)$, a rate which appears to be outstripping that of technology competitors such as GIS, institutional repositories, and data visualization services. ${ }^{13}$ Given the relatively high resource up-front investment required to support VR/XR, it would appear that many university libraries are doubling down on the prospect that VR/XR will be an integral part of their future. The degree to which the rapid adoption of VR/XR will live up its promise remains to be seen, but the present study seeks to illuminate how current librarians are seeking to tame this potentially savage beast.

\section{METHODOLOGY}

This IRB-approved study is based on the qualitative analysis of eleven interviews with thirteen librarians (8), embedded IT staff (3), or faculty members (2), all of whom were involved with the adoption of VR/XR technology at their respective libraries. The inclusion criteria for the study were described in the consent document as those people "currently involved in administering, managing, or planning a virtual reality lab or classroom in a library (or similar unit) in a higher education setting." To identify potential participants, the researchers conducted a web search using the terms "library" and "virtual reality" or "VR" and then utilized a snowball sampling method to generate a list of potential interviewees that included multiple library types (e.g., academic research libraries [ARLs], public libraries) as well as institutional types (e.g., community colleges). One large library had multiple participants including one librarian and two support staff responsible for the VR room. Taken collectively, these participants' institutions included community colleges (3), public libraries (2), medical libraries (4), and academic research libraries (4), located in either the United States (10) or Canada (1). The pool of the US educational institutions (10) represented five different Carnegie classifications: Associate's Colleges, Doctoral Universities, Doctoral/Professional Universities, Master's Colleges \& Universities, and Special Focus Four-Year Institutions. These comprised a mix of small-, medium-, and large-sized institutions (by full-time enrollment, or FTE). All the organizations in this study (11) were public institutions.

Each interviewee received a copy of the possible interview topics in advance, including a list of potential challenges faced by libraries seeking to integrate VR/XR (see appendix A). The list of challenges was crafted from a literature search, as well as the personal experience of one of the researchers, a librarian who oversees a VR lab. Each hour-long, semi-structured interview was conducted via Zoom, machine transcribed with Kaltura, and further edited manually by the researchers. The transcripts then underwent three rounds of coding. First, the researchers independently reviewed the body of transcripts in their entirety and identified emergent themes. In the second round of coding, potential themes were merged into semi-structured coding guidelines, which were used to code each interview separately. In the third and final round, the themes were re-evaluated and adjusted based on feedback from the previous rounds, leading to the identification of a problem-based typology (emergent, complex, wicked). From our process, we gained insight into a myriad of challenges facing libraries as they work to integrate VR/XR into the work that they do. That insight has, in turn, led to the development of a conceptual framework that we believe will be useful to others seeking to wrestle with these challenges in the future. 
Table 1. Equipment, staffing, and funding for VR/XR spaces in participating libraries

\begin{tabular}{|c|c|c|c|c|c|c|c|}
\hline $\begin{array}{c}\text { Location } \\
\text { of VR } \\
\text { service } \\
\text { in library } \\
\end{array}$ & $\begin{array}{c}\text { Number of } \\
\text { PCs } \\
\text { connected }\end{array}$ & \begin{tabular}{|c|}
$\begin{array}{c}\text { Number } \\
\text { of } \\
\text { mobile }\end{array}$ \\
headsets \\
\end{tabular} & $\begin{array}{c}\text { Types of } \\
\text { PC } \\
\text { headsets }\end{array}$ & $\begin{array}{c}\text { Types of } \\
\text { mobile } \\
\text { headsets }\end{array}$ & Staffing & $\begin{array}{l}\text { One time } \\
\text { funding }\end{array}$ & $\begin{array}{l}\text { Continuing } \\
\text { funding }\end{array}$ \\
\hline Room & 2 & 10 & $\begin{array}{l}\text { HTC (Vive } \\
\text { and Pro) }\end{array}$ & $\begin{array}{l}\text { Oculus Go, } \\
\text { Spectra VR }\end{array}$ & 2 staff & Yes & No \\
\hline Entrance & 1 & 0 & $\begin{array}{l}\text { Oculus Rift } \\
\text { SV }\end{array}$ & - & 2 staff & Yes & As needed \\
\hline Room & 4 & 8 & $\begin{array}{l}\text { HTC Vive } \\
\text { Pro }\end{array}$ & $\begin{array}{l}\text { Oculus } \\
\text { Quest and } \\
\text { Microsoft } \\
\text { HoloLens } \\
\end{array}$ & $\begin{array}{l}1 \text { staff, } 3 \\
\text { students }\end{array}$ & Yes & $\begin{array}{l}\text { No, but } \\
\text { planned }\end{array}$ \\
\hline Room & 5 & 1 & $\begin{array}{l}\text { Oculus Rift } \\
\text { S and HTC } \\
\text { Vive Pro }\end{array}$ & $\begin{array}{l}\text { Oculus } \\
\text { Quest }\end{array}$ & $\begin{array}{l}3 \text { staff, } 3 \\
\text { students }\end{array}$ & Yes & As needed \\
\hline $\begin{array}{l}\text { Room, } \\
\text { Mobile VR }\end{array}$ & 1 & $\begin{array}{l}3 \text { in circ, } \\
\text { several } \\
\text { in office }\end{array}$ & $\begin{array}{l}\text { HTC Vive } \\
\text { Cosmos }\end{array}$ & $\begin{array}{l}\text { Oculus } \\
\text { Quest, } \\
\text { Oculus Go, } \\
\text { Samsung } \\
\text { Odyssey, } \\
\text { Lenovo } \\
\text { Mirage Solo, } \\
\text { Hololens, } \\
\text { PlayStation } \\
\text { VR and } \\
\text { Google } \\
\text { Cardboard } \\
\end{array}$ & $\begin{array}{l}2 \text { staff, } 8 \\
\text { students }\end{array}$ & No & As needed \\
\hline $\begin{array}{l}\text { Mobile } \\
\text { VR, } \\
\text { Entrance }\end{array}$ & 2 & 6 & $\begin{array}{l}\text { HTC Vive, } \\
\text { Oculus Rift }\end{array}$ & $\begin{array}{l}\text { Oculus Go, } \\
\text { Oculus } \\
\text { Quest }\end{array}$ & $\begin{array}{l}\text { all circ } \\
\text { staff }(2 / 3 \\
\text { per shift })\end{array}$ & Yes & No \\
\hline Room & 3 & 7 & $\begin{array}{l}\text { Oculus Rift, } \\
\text { HTC Vive } \\
\text { Pro, HTC } \\
\text { Vive } \\
\text { Standard }\end{array}$ & $\begin{array}{l}\text { Google } \\
\text { Cardboard, } \\
\text { Insignia VR } \\
\text { Viewers }\end{array}$ & 2 staff & Yes & $\begin{array}{l}\text { No, but } \\
\text { planned }\end{array}$ \\
\hline $\begin{array}{l}\text { Mobile } \\
\text { VR, } \\
\text { Entrance }\end{array}$ & 4 & 30 & $\begin{array}{l}\text { HTC Vive, } \\
\text { Oculus Rift }\end{array}$ & $\begin{array}{l}\text { Oculus } \\
\text { Quest, } \\
\text { Google } \\
\text { Cardboard } \\
\text { or plastic } \\
\text { viewers }\end{array}$ & $\begin{array}{l}\text { Circ staff at } \\
\text { each of } 4 \\
\text { locations }\end{array}$ & No & Yes \\
\hline
\end{tabular}




\section{RESULTS}

\section{Library VR/XR Spaces}

Even within the relatively small sample of institutions included in our sample, we found that there was a fairly wide range of practice regarding VR/XR library labs, with considerable variance on location, number, and manufacturer of headsets, staffing, and funding as seen in table 1.

\section{CHALLENGES}

Through our coding process, we identified clusters of those challenges, which we categorized as either emergent (but solvable), complicated (but possible), and/or wicked (but tameable).

\section{Emergent Challenges}

Our respondents identified a number of challenges that are frequently associated with the adoption of emergent technology, regardless of who is choosing to adopt it or what they are choosing to adopt. In other words, any person or place adopting XR (or other types of emergent technology) at this stage of its development is likely to run into similar issues.

\section{Portability and Mobility}

Portability (or lack thereof) was frequently referenced as a limitation of the current technology. The most common headsets purchased for the first generation of library VR lab spaces have physical cords and sensors that have to be plugged in (to high performing computers) during use. One intrepid librarian even described carting around her bulky Alienware desktop computers and video displays between campuses, but needing to find a better way because, "it made the computer folks very angry because it's so delicate and our sidewalks are so bumpy." She now uses an Alienware laptop and some sturdy tripods (for the base stations) on these trips. The lack of portability not only limited the ability of libraries to take VR/XR out of the library for events and in-class presentations, but it also exacerbated existing space constraints, with users having to be literally tethered to CPUs, screens, and base stations. As one of our respondents put it, "the biggest issue is that it's in one place and it's stuck there."

In this case, manufacturers are aware of the limitations on mobility, and it appears as though wireless headsets will be the next wave of adaptation by the industry. Several wireless headsets have already come and gone, as vendors continue to work to overcome both technological and human-centered challenges. The Oculus Go, Google Cardboard, and Google Daydream have all been brought to the market and subsequently been discontinued. ${ }^{14}$ Only one of the libraries we spoke to indicated that they had purchased a wireless headset, and that headset (the Oculus Go) turned out to be of limited utility. While this next generation of headsets will likely solve a number of operability issues, it also has the potential to compound another challenge noted by most of our respondents, i.e., a lack of sustainable funding for equipment refresh. The majority of our respondents ( 6 of 8 , or $75 \%$ ) indicated that they purchased their equipment through one-time funding sources, whether internal or external grants $(n=6)$, end-of-year funds, or some combination of these.

\section{$V R / X R$ Training}

VR/XR experience remains new to most people outside of the gaming world, so it has fallen largely on librarians to develop introductory training protocols at the level of access to the technology. There are distinctive challenges in introducing VR/XR to a broader audience. Some of those challenges may be physical. In its earlier stages, a number of users experienced symptoms such as nausea or seasickness, and while these have been lessened with higher refresh rates and movable 
lenses, other virtual reality induced symptoms and effects (VRISE) continue to emerge with studies of longer-term use. ${ }^{15}$ Two of our librarians expressed concerns that other long-term effects may still be unknown, and both of the public libraries included in this study banned VR/XR use for patrons under 14 years of age until more is known about how it affects developing brains, a recommendation that is now supported by most vendors as well. Even for those who do not suffer from physical symptoms, the technology can be disorienting and uncomfortable. This contributes to higher levels of anxiety, which, somewhat ironically, VR/XR has been shown to alleviate in some clinical trials. ${ }^{16}$

For these reasons, VR/XR labs require staffing not just to safeguard the equipment and ensure its appropriate use, but also to coach users through their new experience. As one of our respondents described her experience, "A lot of people will put on the VR headset and not move because they're used to computer displays being two-dimensional ... it is not common knowledge yet that you can move around and this environment [moves] with you. And they [new users] will just stand there." Coaching someone to move around in a virtual reality environment is not a straightforward endeavor either, as one of our librarians relates: "How do you interact with somebody who can't see you in a way that's respectful? Because that can be kind of disconcerting if you've got a headset on and all of sudden somebody touches your hand?" One of our respondents drew upon her experience as a swimming coach to develop a set of "non-touching" verbal protocols for her student lab assistants to utilize in working with clients who are new to the interior mobility of virtual worlds.

Other challenges identified by our respondents that might fit into the emerging technologies category include the following: liability, aspects of licensing, physical space modifications, room and equipment management, training curriculum, logistics of engaging with multiple users, availability of apps/games, equipment installation, and evaluation procedures. This list could perhaps also include the need to not only educate patrons on what the emerging technology can do but to advocate for its future significance. As one of our respondents stated, "I think you can write about it and speak about as much as you want. It's a matter of getting them in there."

\section{Complicated Challenges}

Unlike emergent issues, complicated challenges are unlikely to be resolved without concerted intervention and leadership and, even then, it is possible that a single or clear solution may not be readily identified. Challenges that fall into this category may be described as grey areas, in which future directions remain scattered, unclear, or uncertain. Embracing these complexities means that libraries looking to adopt VR/XR currently must be willing to venture out on their own, embracing both the opportunities and the risks inherent in forecasting future technology use.

\section{Licensing}

An example of one of these complicated challenges that emerged from our interviews is the issue of licensing. Many VR/XR titles are available for free, through services such as Steam and the Oculus store. All of our respondents indicated that they acquired content via these services. Other popular VR/XR academic titles, such as 3D Organon Anatomy and Google Tilt brush, are licensed and potential users must pay a fee to access the full functionality of the tool. The challenge is that these licenses are most offered on an individual basis ("for home use only"), a reflection of the primary customer base for VR/XR content creators, e.g., gamers. A number of distributors do offer institutional licenses, but these are primarily for use in companies, with a relatively stable and readily identifiable list of employee users or limited number of stations. Some VR/XR distributors 
offer a lesser-known (and less used) license known as an arcade license (e.g., Steam PC Café), but the prices are determined based on the assumption that the person renting the software for use will be receiving a fee, an assumption which does not work for libraries who do provide arcadelike services but do so free of charge.

In other words, none of these available license types are well-suited for library use; the former too limited, the latter too expensive. As one of our librarians suggested, this is the "sort of the crack that libraries fall into a lot of the time anyway, with regard to [issues such as] document delivery, right, [in which the rule is stated], but it probably doesn't apply to us in the same way because we're a library. But it doesn't explicitly say what I need to do about it." What this means is that the majority of the librarians we spoke with indicated that they adopted one or more of these license types, but there was discomfort with the maladaptation to library practice and uncertainly as to what might constitute a best practice in the current market space.

In the case of VR/XR, this state of affairs is likely due, at least in part, to a lack of awareness of or concern for libraries (or educational labs) as customers on the part of vendors. Our respondents indicated that this oversight may be changing, however, as four of the librarians we interviewed reported that game developers reached out to them and negotiated deals in which libraries would receive equipment in exchange for beta-testing new titles with student populations. That said, awareness does not equate to priority, as one of our respondents noted, "I am concerned that we will be one of the last audiences that get some consideration in terms of the functionality that meets the library's needs." Even if these issues are resolved in the context of VR/XR specifically, it seems unlikely that the complicated problem of "library as customer" will persist with the advent of new technologies and new technology providers.

\section{Ethics}

The challenge of vendor relationships is compounded by other emergent ethical issues surrounding the integration of VR/XR into the library. Several of the ethical concerns raised by our interviewees are connected to broader social concerns with technology use, such as issues of privacy and security, and others are related to long-standing ethical debates within libraries, such as the degree to which content should be limited by the library. Our interviewees had divided opinions, for example, on whether or not the VR/XR lab should offer games. On one hand, the availability of games brought students to the library and engaged them with the new technology. On the other hand, the provision of games constitutes, for some stakeholders, a potentially significant shift away from an academic or scholarly mission for the library. As one respondent put it, "I can't say that libraries have traditionally not been a place for people to have fun, but I think that's something that ... rubs some people a little bit the wrong way." Another stated, "My big concern at the beginning was that we would put this in and people would [say] ... that's for video games. Why did the library buy video games?"

The question of including popular content should be a familiar debate to librarians, but the issue is ratcheted up a notch when engagement may also include actions, such as shooting, that may be especially sensitive for college campuses. As one interviewee reflected, "We are a university in the South. And if you had a bunch of white male students that love to go play this game, is that going to make somebody from another group feel uncomfortable or unwelcome or feel like this is not a space for them?" As this example implies, unlike the often private act of reading, VR/XR experiences often take place in virtual places that are at least quasi-public, a venue for which few ethical precedents exist (yet). Conversations on the legal and ethical implications of fully virtual 
crimes, such as rape or robbery, for example, constitute a lively, but so far unresolved, scholarly conversation. ${ }^{17}$

\section{Wicked Problems}

Where the challenges faced by libraries get most complicated, however, is when the integration of VR/XR touch upon the more fundamental question of the appropriate roles for libraries in the digital age. Our respondents framed their VR labs and services largely within existing roles, e.g., gateway or learning partner, with some attention to emerging roles, such as maker, but they also acknowledged that this adaptation was awkward, solutions were (often) makeshift, and anomalies persist. This suggests the potential for paradigm shifts in the role(s) libraries can play in shaping the intersections of knowledge between the "real" and virtual worlds.

\section{Library as Gateway}

A number of our respondents connected the library's adoption of VR/XR technology to its role in providing access to technology for those who may not otherwise have it. This role was especially pronounced in the case of academic libraries located in public universities and public libraries serving a defined community. As one of the respondents described their role, "We're pleased to have them come and learn how to use these technologies because they're new and we're trying to make it more democratized that students can come and use it. They don't have to pay for it. They don't have to worry about like a lab being locked away from them. They can come in anytime there's a staff member and use the stuff where here it will provide them tutorials and instruction if they want to use it." Similarly, another respondent stated, "Libraries ... offer an entry-level kind of way to engage with this technology in a free way where anyone who is even remotely curious, even if it doesn't have anything to do with ... anything academic, can engage with this stuff." A third respondent stated that the case they made internally (to their library colleagues) was "to explain the importance of the library philosophy of having equitable access to resources ... books are a resource, but technology is also a resource."

We have characterized this role as a gateway, rather than strictly as an access issue, because it also encompasses a vision of a pathway, one which starts in the library but may continue to other places, whether specialized labs in the discipline, in the workforce, or as part of their everyday lives. As one of our respondents put it, "We're very much about these technologies. They're here; they're coming; they're going to be a big thing soon. And we want our students to know what they are and be comfortable with them. So, we try to position ourselves as a place where they can start learning."

This gateway function is, however, characterized by competing stakeholders, both inside and outside of the library-a defining characteristic of wicked problems. This latter is perhaps best illustrated by looking at issues of accessibility. As the statements above attest, librarians see one of their primary service roles as providing access to technologies such as VR/XR to people who might not otherwise have it. That same sentiment, though, can be flipped on its head when taking other aspects of accessibility into consideration. Most VR/XR programs are not ADA compliant, whether they are being offered in the physical or virtual public spaces of the library. In its current form, VR/XR is an inherently visual technology, so those who are visually impaired cannot utilize it to the same extent as others. Most VR/XR programs require physical movements that may not be possible for those with limited mobility. Our librarians have created a few hacks, or workarounds, to provide short-term accommodations for individual students (e.g., a verbal narration of visual interactions), but generally speaking, the technology is not fully accessible. 


\section{Library as Learning Partner}

Several of our respondents indicated that they saw the library's adoption of VR/XR technology as an extension of their role as partners in the learning enterprise. This role could be conceived directly, in that the librarian mediates between classroom needs and available VR/XR titles and capabilities. This form of direct mediation could be responsive, i.e., identifying options in response to requests received, or proactive, i.e., identifying options than reaching out to faculty who might wish to avail themselves of them.

Integrating VR/XR Material into the Library's ILS

The role is especially critical at this stage of VR/XR development, as none of the libraries we spoke to had integrated the available titles into their online, public-facing catalogs or integrated library system (ILS). In other words, if a patron wants to know what titles are available, the best way to find out would be to ask the librarian directly and/or visit the VR/XR lab in person. As one librarian put it, "There's not the infrastructure or the architecture we have around a book. If you were, say, a student in a history class and you wanted to study this thing, there's no way to discover that as part of the more general resources of the library." Several of our respondents were developing workarounds, such as LibGuides and web-based directories, but none of these would be accessible through a general search of the library catalog or citation databases.

Determining how to catalog and/or curate VR/XR artifacts may be challenging and timeconsuming, but it is a problem that has an eventual solution. What is less clear, however, is what the long-term role of the library may be beyond this cataloging function. Our respondents consistently indicated that this remains one of the lesser-developed roles for VR/XR in the library, and many identified raising faculty awareness especially as a high priority. While several identified this as essentially a "marketing problem," it would appear that the challenge extends more deeply. Many librarians do not have additional degrees in either educational development or instructional design, which encompasses the practice of matching learning outcomes to technology tools. The two most successful examples of matching learning outcomes to librarybased VR/XR that we heard of were faculty driven, one a project to scan actual human body parts for use in a VR setting; the other a criminal justice project related to empathy education using virtual encounters.

These kinds of alignment activities can only occur if there is a tool available to match the proposed learning outcome. Most of our respondents lamented the limited availability of titles that are appropriate for use in academic settings, so even if awareness was raised, there may not be sufficient content to meet academic needs. As one librarian suggests, "Students will say, I've seen the anatomy tool, but right now I'm taking chemistry or I'm taking genetics. Do you have anything that will help me with that? I'm a visual learner. I really liked this format. And that's been challenging for because it's so new. There's not a coherence in terms of the titles and subject areas that you get." And another characterized the issue this way, "It's like the bargain video bin at Walmart. Sometimes you have to dig through to find something because it's just, it's so new right now."

The issue of availability may seem like an emergent technology issue (as above), but the challenge is further compounded by limitations on capacity, as most library VR labs can only hold one class at a time, and even then, the numbers may be limited, necessitating workarounds such as rotations, remote screen-casting, or extended office hours. Even with multiple headsets, most of the time students cannot be in the same virtual reality space together. Despite these challenges, 
many of our respondents were focused on optimizing current capacities, at least in part because of pressure to justify the continued expenditure of both personnel time and equipment costs. This precarious state of affairs is reflective both of tightening university budgets as well as the frequent present of internal sources of resistance from more traditionally-minded colleagues within the library itself (noted tactfully by three of our respondents). Bearing all of these factors in mind, it would seem that the question of the long-term sustainability and scalability of VR/XR as a learning service for libraries remains unresolved.

\section{Library as Maker}

There may be another way to frame VR/XR in the context of libraries. In several cases ( $n=3)$, our respondents framed VR/XR not as an extension of classroom-focused service, but rather of support for the research enterprise. As one of our respondents described it, "If they're still working on a project and they need a thing for this academic project. And then we're just providing a new way to provide that service, closing some of the research cycle loop, that we're now part of a different part of that same loop of creating things." This is a reflection of the changing nature of outputs from scholarly research. Previously confined largely to print artifacts, e.g., peer-reviewed journals, researchers are facing an increasing number of choices when it comes to ways to represent the scholarship being created, e.g., knowledge artifacts. This can include artifacts created in, through, or with VR/XR.

Several of the librarians $(n=4)$ we spoke to mentioned that their VR/XR lab came packaged, in a sense, along with their 3D printing stations. In each case, the librarians noted that the utility of the 3D printers had resonated more readily with library users, and two indicated that they had aspirations to link the two processes in an effort to boost interest in the VR/XR space. For example, one respondent indicated that they wanted users to be able to create an object in a VR/XR program, such as Google Tilt Brush, and then print their creation on an associated 3D printer. Libraries have long provided non-3D printing services, largely as ancillary services to support researchers, so this example may, at first glance, appear to be simply a slightly more hightech version of a pre-existing service. These made objects, too, could potentially be stored, cataloged, and disseminated through the library system and/or via a dedicated database such as SketchFab.com.

In our interviews, however, the respondents hinted that this linkage (between VR/XR and 3D printing) may actually be a first step towards a more fundamental shift in re-imagining the role of the library vis-à-vis technology. Rather than functioning primarily as service providers, emerging technology librarians have the opportunity to become more active (co-)creators of content and facilitators of change. In one case, the VR/XR lab director, also a faculty member, developed partnerships with strategic programs on campus, such as the office of admissions, to generate original content that was specific to their institution. Fortunately, the faculty member was able to draw on coding skills she had gained in prior professional roles. In another case, the library partnered with an external developer to generate original content with direct relevance to the community - a project that served to generate interest in the library, VR/XR, and local issues, all at the same time.

There is a fundamental difference between a library hosting a maker space and becoming a maker itself. While librarians have traditionally characterized themselves as facilitators of knowledge rather than knowledge creators, there is some evidence that this shift may not be quite as profound as it might appear. This shift began with libraries and librarians scanning digitized items 
of their siloed special collections and archives. The resulting databases are often treated as published works in and of themselves with the library acting as curator and publisher. In addition, librarians currently hold faculty rank at many research universities and actively present and publish both in library-focused journals, thematic journals (e.g., information literacy), as well as in other venues, often alongside faculty partners. ${ }^{18}$ The embedded curricular model places librarians in the role of learning designers and as creators of extended, discipline-specific content. It should be noted, too, that content development is not the only "creator" role available. When you build a knowledge management system (like a library catalog), the choices you make serve not just to organize knowledge, but also, to shape that knowledge and, yes, create physical and cognitive pathways to and through it. ${ }^{19}$ It is perhaps not a coincidence that identifying pathways has been identified as a signature taming strategy for wicked problems.

\section{DISCUSSION: TAMING WICKED PROBLEMS}

Our study frames the adoption of VR/XR technology by academic libraries as embedded in the larger wicked problem of library reinvention in a digital age. That said, one of the fundamental characteristics of a wicked problem is not that it is very difficult to solve, but that it is intrinsically unsolvable (or nearly so). This may explain why the question of libraries and technology seems to be a conversation that never goes away, as the question involves a perpetually moving target, embedded in the ever-shifting social, economic, and political dynamics that are taking place well beyond the walls of any library. ${ }^{20}$ This characterization does not mean, however, that we should not keep trying a variety of strategies to untangle these wicked knots.

\section{Taming Strategy 1: Embracing Wickedness}

In a recent essay about learning in higher education, Randy Bass characterized the wicked problem designation as potentially liberating, rather than discouraging. Embracing wickedness serves to move the conversation from thinking of libraries as broken or backward (and therefore, in need of solutions), to a view of the question as a grand challenge, a continual thought experiment that requires ongoing inquiry, thoughtful consideration, and an expansive, rather than reductive, perspective. ${ }^{21}$ As a grand challenge, the question of libraries and emerging technologies such as VR/XR becomes less of a mad scramble to maintain relevance and more of a scholarly conversation that enhances the role of the library as an inclusive and pluralistic space. In this framework, the questions of whether or not a library should embrace new technology or technology-related service are not bounded by the intrinsic qualities of that technology itself, nor does it mean that libraries everywhere will need to land upon the same, or even similar, technologies, but rather they might seek convergence in the role of libraries as tamers of these wicked problems.

\section{Taming Strategy 2: Integrating Adaptability}

The librarians we spoke to generally described their units as falling under the category of "early majority" in Roger's well-known diffusion of technology model, in that they wanted to see evidence that VR/ XR will be useful to others before committing their resources, but they also want to serve a gateway role in introducing promising new technologies to their patrons. ${ }^{22}$ Much of the research on technology diffusion, however, has focused on either end of the curve, i.e., the innovators or non-innovators, and comparatively less research has been done on the role played by those in the middle, such as these libraries. ${ }^{23}$ By positioning themselves as early majority adopters, academic libraries would potentially be able to articulate a clear and distinct role for themselves vis-à-vis other units within the university that support technology-enabled learning; 
while also giving themselves the ability to leverage more resources outside of the library itself. The model also has the advantage of providing a sustainable model of re-invention. As a given technology matures along the continuum, the library's role recedes, enabling it to embrace the next emerging technology. As one of our respondents pointed out, their library used to give training on how to use a mouse and, one day, gateway training for VR is likely to go the same route.

\section{Taming Strategy 3: Building Networks}

Because wicked problems are complex and ill-defined, taming them is often done by connecting to others with different perspectives. ${ }^{24}$ Our respondents were largely emerging technology librarians who used a number of on-the-ground strategies to tame the wickedness of the task of advocating for a vision of VR/XR on their respective campuses. Most of these strategies required creating relationships beyond the walls of the library, e.g., building organizational networks, connecting to community organizations, developing joint, shared, or embedded positions; cultivating faculty champions in academic units, and initiating shared programming. These collaborative strategies resonate with another characteristic of wicked problems, e.g., that they require the ability to think across conventional organizational and disciplinary siloes.

\section{Taming Strategy 4: Exercising Interdisciplinary Imagination}

And what other role at a university has more experience with this kind of intellectual dexterity than a librarian? Our respondents mentioned working with faculty from 14 different disciplines in the context of their responses to our interview questions, and that's without being asked. As higher education increasingly shifts its attention towards addressing wicked problems, then librarians may be well poised to serve a gateway role in modeling, supporting, and conducting what is now being called "convergent" research. ${ }^{25}$ This has been described as transdisciplinary inquiry that integrates knowledge from multiple data sources, disciplinary perspectives, and lived experiences in order to confront the world's most complex problems. ${ }^{26}$

\section{Taming Strategy 5: Modeling}

As learning partners in the future of higher education, librarians will have a role to play in developing our students' abilities to tame these same wicked problems. ${ }^{27}$ This partnership is not limited to the kind of information and digital literacy needed for cross-disciplinary research. Taming wicked problems requires more than a specific set of knowledge or skills, but rather a certain disposition, e.g., a willingness to engage in answering seemingly impossible questions; the flexibility to find pathways through those challenges; the ability to persevere through short-term setbacks; and, above all else, the motivation to support the ability of others to flourish. ${ }^{28}$ This same set of wicked qualities could easily be applied to all of the respondents in our study, each of whom have succeeded because of their deeply held, intrinsic passion for (and commitment to) the possibilities for what technology and libraries can do together.

\section{CONCLUSION}

The library remains a model of not just individual, but also organizational resiliency. As new technologies such as VR/XR arise, the library as an institution will find ways to weather emerging challenges, resolve complicated problems, and disentangle super complex, i.e., wicked, dilemmas, each of which requires the cultivation of distinctive knowledge, skills, and dispositions. In this study, we argue that the strategies associated with wicked problem solving can serve to strengthen the ability of libraries (and librarians) to serve an active role in our collective future, whether that future is "real" or virtual (or both). 


\section{APPENDIX A - EMAIL TO INTERVIEWEES}

Subject: We are interested in your experience with virtual reality at your library/university/college - A research study interview request

Hi Invitee,

You are being invited to participate in a research study of how universities navigate the integration of virtual reality labs. You were selected as a possible participant because of your experience in managing or implementing such labs. Your participation entails a 45-60 minute interview, conducted through Zoom.

We will be especially interested in how you, your library, or your university navigated one of the following "grey areas" where a situation is ill-defined or not readily conforming to a category or an existing set of rules or policies. These include but not limited to your professional perspective in one or more of the following:

1. Physical and software liability

2. Licensing and infringement

3. User accounts with the university and/or with the vendor

4. Physical space modifications needed for VR

5. Room and equipment management

6. Separating collection development policies from equipment and use policies

7. Use policies for the equipment, software, and users

8. Controlling the VR equipment and software

9. Time, research, and staff needed to run this service

10. Training and learning curve for users (both faculty and students)

11. Logistics of using the VR room for a class and within a class

12. Integrating VR into a college course

13. Selecting appropriate VR items to purchase

14. Evaluating VR items

15. Paying for VR items including approval, licensing, purchasing processes

16. Installing and maintaining VR items including regular updates, the user installing software/games, management of hardware/software, repair, etc.

17. Budget for VR (amount, repair, one-time/continuing)

18. A VR topic of your choice

Of course, we will not be able to cover all of these areas listed above during our short interview with you. We are sending them so you can begin thinking about these VR challenges and prioritize them. Based on our own experience, we think you have important insight to share about some of them that will be beneficial to the broader university and library communities. 


\section{APPENDIX B - INTERVIEW PROTOCOL}

1. Tell us about the history of you/your library with VR.

2. How have you/your library navigated one of the following grey areas (drawn from working with VR in libraries) where a situation is ill-defined or not readily conforming to a category or an existing set of rules or policies? These include but are not limited to your professional perspective in one or more of the following (from the list we sent you in our invitation email):

- $\quad$ Physical and software liability

- $\quad$ Licensing and infringement

- User accounts with the university and/or with the vendor

- $\quad$ Physical space modifications needed for VR

- $\quad$ Room and equipment management

- $\quad$ Separating collection development policies from equipment and use policies

- Use policies for the equipment, software, and users

- $\quad$ Controlling the VR equipment and software

- $\quad$ Time, research, and staff needed to run this service

- $\quad$ Training and learning curve for users (both faculty and students)

- $\quad$ Logistics of using the VR room for a class and within a class

- Integrating VR into a college course

- $\quad$ Selecting appropriate VR items to purchase

- $\quad$ Evaluating VR items

- $\quad$ Paying for VR items including approval, licensing, purchasing processes

- Installing and maintaining VR items including regular updates, the user installing software/games, management of hardware/software, repair, etc.

- $\quad$ Budget for VR (amount, repair, one-time/continuing)

- A VR topic of your choice

Please describe an occasion where you were faced with one of these complex, challenging, and/or potentially insurmountable obstacles in integrating VR into your library (or university more broadly). How did you navigate this challenge?

3. Please describe one way in which the values, practices, and ethos of librarianship may have been challenged by the integration of a VR lab and the purchase and curation of VR artifacts. 


\section{ENDNOTES}

${ }^{1}$ Horst W. J. Rittel and Melvin M. Webber, “Dilemmas in a General Theory of Planning," Policy Sciences 4, no. 2 (1973): 155-69.

${ }^{2}$ Cameron Tonkinwise, “Design for Transitions-From and to What?” Design Philosophy Papers 13, no. 1 (May 2015): 15, http://dx.doi.org/10.1080/14487136.2015.1085686.

${ }^{3}$ Valerie A. Brown, John Harris, and Jacqueline Russell, Tackling Wicked Problems: Through the Transdisciplinary Imagination (London: Taylor \& Francis Group, 2010): 302, Ebook Central.

${ }^{4}$ Bayard L. Catron, “On Taming Wicked Problems,” Dialogue 3, no. 3 (1981): 13-16; Luke Houghton, "Engaging Alternative Cognitive Pathways for Taming Wicked Problems," Emergence : Complexity and Organization 17, no. 1 (2015), https://www.researchgate.net/publication/282282336 Engaging alternative cognitive path ways for taming wicked problems A case study.

${ }^{5}$ Catron, "On Taming Wicked Problems"; Falk Daviter, "Coping, Taming or Solving: Alternative Approaches to the Governance of Wicked Problems," Policy Studies 38, no. 6 (November 2017): 571-88, https://doi.org/10.1080/01442872.2017.1384543; David J. Snowden and Mary E. Boone, “A Leader's Framework for Decision Making," Harvard Business Review (November 1, 2007), https://hbr.org/2007/11/a-leaders-framework-for-decision-making.

${ }^{6}$ Natallia Pashkevich, "Wicked Problems: Background and Current State," Philosophia Reformata 85, no. 2 (November 4, 2020): 119-24, https://doi.org/10.1163/23528230-8502A008.

${ }^{7}$ Andrew M. Cox, Mary Anne Kennan, Liz Lyon, and Stephen Pinfield, "Developments in Research Data Management in Academic Libraries: Towards an Understanding of Research Data Service Maturity," Journal of the Association for Information Science and Technology 68, no. 9 (2017): 2182-2200, https://doi.org/10.1002/asi.23781; Julie McLeod and Sue Childs, "A Strategic Approach to Making Sense of the 'Wicked' Problem of ERM," Records Management Journal 23, no. 2 (2013): 104-35, http://dx.doi.org/10.1108/RMJ-04-2013-0009; Shelley Wilkin and Peter G. Underwood, "Research on E-Book Usage in Academic Libraries: 'Tame' Solution or a 'Wicked Problem'?" South African Journal of Libraries \& Information Science 81, no. 2 (July 2015): 1118, https://doi.org/10.7553/81-2-1560; Brendan Howley, “Libraries, Prosperity's Wicked Problems, and the Gifting Economy," Information Today 33, no. 6 (July 2016): 14-15, ProQuest.

${ }^{8}$ Rachel D. Williams and Rebekah Willett, "Makerspaces and Boundary Work: The Role of Librarians as Educators in Public Library Makerspaces," Journal of Librarianship and Information Science 51, no. 3 (September 2019): 801-13, https://doi.org/10.1177/0961000617742467.

${ }^{9}$ Cox, Pinfield, and Smith, "Moving a Brick Building."

${ }^{10}$ Matt Cook et al., "Challenges and Strategies for Educational Virtual Reality," Information Technology and Libraries 38, no. 4 (December 16, 2019): 25-48, https://doi.org/10.6017/ital.v38i4.11075; Kung Jin Lee, W. E. King, Negin Dahya, and Jin Ha Lee, "Librarian Perspectives on the Role of Virtual Reality in Public Libraries," Proceedings of the Association for Information Science and Technology 57, no. 1 (2020): e254, https://doi.org/10.1002/pra2.254; Hannah Pope, "Virtual and Augmented Reality in 
Libraries," Library Technology Reports 54, no. 6 (September 8, 2018): 1-25; Felicia Ann Smith, "Virtual Reality in Libraries Is Common Sense,"' Library Hi Tech News 36, no. 6 (August 28, 2019): 10-13, https://doi.org/10.1108/LHTN-06-2019-0040; Char Booth, "From Technolust to Technorealism," Public Services Quarterly 5, no. 2 (June 2009): 139-42, https://doi.org/10.1080/15228950902868504.

${ }^{11}$ Megan Frost, Michael Goates, Sarah Cheng, and Jed Johnston, "Virtual Reality: A Survey of Use at an Academic Library," Information Technology and Libraries 39, no. 1 (March 2020): 1-12. https://doi.org/10.6017/ital.v39i1.11369; Jennifer Grayburn, Zack Lischer-Katz, Kristina Golubiewski-Davis, and Veronica Ikeshoji-Orlati, 3D/VR in the Academic Library: Emerging Practices and Trends (Washington, DC: Council on Library and Information Resources, 2019), https://eric.ed.gov/?id=ED597662; Susan Lessick and Michelle Kraft, "Facing Reality: The Growth of Virtual Reality and Health Sciences Libraries," Journal of the Medical Library Association: JMLA 105, no. 4 (October 2017): 407-17, https://doi.org/10.5195/imla.2017.329; Kenneth J. Varnum, ed. Beyond Reality: Augmented, Virtual, and Mixed Reality in the Library (Chicago: American Library Association, 2019); Richard Smith and Oliver Bridle, "Using Virtual Reality to Create Real World Collaborations," Proceedings of the IATUL Conferences. Paper 5 (2018): 10, https://docs.lib.purdue.edu/iatul/2018/collaboration/5/; Carl R. Grant and Stephen Rhind-Tutt, "Is Your Library Ready for the Reality of Virtual Reality? What You Need to Know and Why It Belongs in Your Library," in O, Wind, If Winter Comes, Can Spring Be Far Behind? (Charleston Conference, 2019), https://doi.org/10.5703/1288284317070; Dorothy Carol Ogdon, "Hololens and Vive Pro: Virtual Reality Headsets," Journal of the Medical Library Association: JMLA 107, no. 1 (January 2019): 118-21, https://doi.org/10.5195/imla.2019.602.

${ }^{12}$ Grayburn et al., 3D/VR in the Academic Library, 8.

${ }^{13}$ Douglas Bates, "Library Service Study," unpublished data, June 2, 2020; Andrew M. Cox, Mary Anne Kennan, Liz Lyon, and Stephen Pinfield, "Developments in Research Data Management in Academic Libraries: Towards an Understanding of Research Data Service Maturity," Journal of the Association for Information Science and Technology 68, no. 9 (2017): 2182-2200, https://doi.org/10.1002/asi.23781; Priti Jain, "New Trends and Future Applications/Directions of Institutional Repositories in Academic Institutions," Library Review 60, no. 2 (2011): 125-41, http://dx.doi.org/10.1108/00242531111113078; Janice G. Norris and Elka Tenner, "GIS in Academic Business Libraries: The Future," Journal of Business \& Finance Librarianship 6, no. 1 (September 2000): 23, https://doi.org/10.1300/J109v06n01 03.

${ }^{14}$ Ross Rubin, "Vendors Face the Tough Reality of Affordable VR," ZDNet (July 13, 2020), https://www.zdnet.com/article/vendors-face-the-tough-reality-of-affordable-vr/.

${ }^{15}$ Sarah Sharples, Sue Cobb, Amanda Moody, and John R. Wilson, "Virtual Reality Induced Symptoms and Effects (VRISE): Comparison of Head Mounted Display (HMD), Desktop and Projection Display Systems." Displays 29, no. 2 (March 1, 2008): 58-69, https://doi.org/10.1016/j.displa.2007.09.005.

${ }^{16}$ Emily Carl et al., "Virtual Reality Exposure Therapy for Anxiety and Related Disorders: A MetaAnalysis of Randomized Controlled Trials," Journal of Anxiety Disorders 61 (January 1, 2019): 27-36, https://doi.org/10.1016/j.janxdis.2018.08.003. 
${ }^{17}$ Edward Castronova, On Virtual Economies, (Rochester, NY: Social Science Research Network, July 1, 2002), https://papers.ssrn.com/abstract=338500.

${ }^{18}$ Barbara I. Dewey, “The Embedded Librarian: Strategic Campus Collaborations," Resource Sharing \& Information Networks 17, no. 1/2 (March 2004): 5-17; Alessia Zanin-Yost, "Academic Collaborations: Linking the Role of the Liaison/Embedded Librarian to Teaching and Learning," College \& Undergraduate Libraries 25, no. 2 (April 2018): 150-63, https://doi.org/10.1080/10691316.2018.1455548.

${ }^{19}$ Xiaoping Sheng and Lin Sun, “Developing Knowledge Innovation Culture of Libraries," Library Management 28, no. 1/2 (January 9, 2007): 36-52, https://doi.org/10.1108/01435120710723536.

${ }^{20}$ Lorcan Dempsey, "Libraries and the Informational Future: Some Notes," Information Services \& Use 32, no. 3/4 (July 2012): 201-12, https://doi.org/10.3233/ISU-2012-0670.

${ }^{21}$ Randall Bass, "What's the Problem Now?" To Improve the Academy: A Journal of Educational Development 39, no. 1 (Spring 2020), https://doi.org/10.3998/tia.17063888.0039.102; Kate Crowley and Brian W. Head, “The Enduring Challenge of 'Wicked Problems': Revisiting Rittel and Webber," Policy Sciences 50, no. 4 (December 1, 2017): 539-47, https://doi.org/10.1007/s11077-017-9302-4.

${ }^{22}$ Brady D. Lund, Isaiah Omame, Solomon Tijani, and Daniel Agbaji, "Perceptions toward Artificial Intelligence among Academic Library Employees and Alignment with the Diffusion of Innovations' Adopter Categories," College \& Research Libraries 81, no. 5 (July 2020): 865-82, https://doi.org/10.5860/crl.81.5.865.

${ }^{23}$ David A. Abrahams, "Technology Adoption in Higher Education: A Framework for Identifying and Prioritising Issues and Barriers to Adoption of Instructional Technology," Journal of Applied Research in Higher Education 2, no. 2 (2010): 34-49, https://doi.org/10.1108/17581184201000012.

24 Tilmann Lindberg, Christine Noweski, and Christoph Meinel, "Evolving Discourses on Design Thinking: How Design Cognition Inspires Meta-Disciplinary Creative Collaboration," Technoetic Arts: A Journal of Speculative Research 8, no. 1 (May 2010): 31-37, https://doi.org/10.1386/tear.8.1.31/1; Nancy Roberts, "Wicked Problems and Network Approaches to Resolution," International Public Management Review 1, no. 1 (2000): 1-19.

${ }^{25}$ Heather Leary and Samuel Severance, "Using Design-Based Research to Solve Wicked Problems," ICLS 2020 Proceedings (June 2020): 1805-6, https://repository.isls.org/bitstream/1/6452/1/1805-1806.pdf; Deborah L Mulligan and Patrick Alan Danaher, "The Wicked Problems of Researching Within the Educational Margins: Some Possibilities and Problems," in Researching Within the Educational Margins: Strategies for Communicating and Articulating Voices, ed. Deborah L. Mulligan and Patrick Alan Danaher, (Cham, Switzerland: Palgrave Macmillan, 2020): 23-39, https://doi.org/10.1007/978-3-03048845-12. 
${ }^{26}$ Brown, Harris, and Russell, Tackling Wicked Problems, Ebook Central; Chris Burman, Marota Aphane, and Naftali Mollel, "The Taming Wicked Problems Framework: Reflections in the Making," Journal for New Generation Sciences 15 (April 20, 2018): 51-73, https://www.researchgate.net/publication/324646298 The Taming Wicked Problems Fram ework reflections in the making; "Convergence Research at NSF," National Science Foundation," accessed October 21, 2021, https://www.nsf.gov/od/oia/convergence/.

${ }^{27}$ Alex Jorgensen and Kara Lindaman, "Practicing Democracy on Wicked Problems Through Deliberation: Essentials for Civic Learning and Student Development," Journal of Management Policy and Practice 21, no. 2 (2020): 28-39, https://www.proquest.com/scholarlyjournals/practicing-democracy-on-wicked-problems-through/docview/2435720594/se-2; Paul Hanstedt, Creating Wicked Students: Designing Courses for a Complex World (Sterling, Virginia: Stylus Publishing, 2018), Ebook Central.

${ }^{28}$ Ronald Barnett, “Learning for an Unknown Future," Higher Education Research \& Development 31, no. 1 (February 1, 2012): 65-77, https://doi.org/10.1080/07294360.2012.642841; Stephanie Wilson and Lisa Zamberlan, "Design for an Unknown Future: Amplified Roles for Collaboration, New Design Knowledge, and Creativity," Design Issues 31, no. 2 (Spring 2015): 3-15, https://doi.org/10.1162/DESI a 00318; Robin Kundis Craig, "Resilience Theory and Wicked Problems," Vanderbilt Law Review 73, no. 6 (December 2020): 1733-75, ProQuest; Larry J Leifer and Martin Steinert, "Dancing with Ambiguity: Causality Behavior, Design Thinking, and Triple-Loop-Learning," Information Knowledge Systems Management 10, no. 1-4 (March 2011): 151-73. 